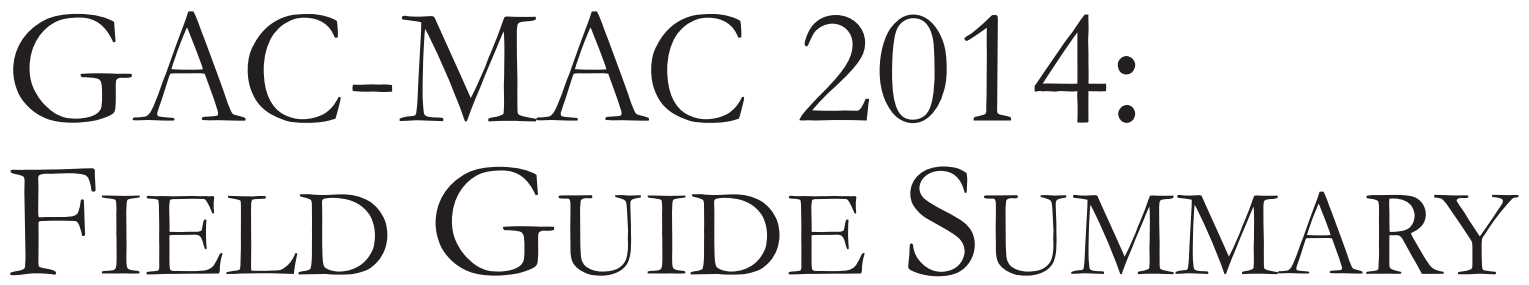

\section{Geoheritage and Geotourism in Stonehammer Geopark: North America's First Global Geopark}

GAC-MAC Fredericton 2014,
post-meeting field trip

Randall Miller, ${ }^{1,2}$, Gail Bremner ${ }^{2}$ and Lucy Wilson ${ }^{3}$

${ }^{1}$ New Brunswick Museum

277 Douglas Avenue

Saint John, NB, Canada, E2K 1E5

Email:Randall.Miller@nbm-mnb.ca

${ }^{2}$ Stonehammer Geopark,

1 Market Square

Saint John, NB, Canada, E2L 4Z6

${ }^{3}$ Department of Geology

P.O. Box 5050

University of New Brunswick.

Saint John, NB, Canada, E2L 4L5

\section{FIELD TRIP OBJECTIVES}

In 2010 Stonehammer Geopark (Fig. 1), located in southern New Brunswick, became the first North American member of the Global Geoparks Network, an organization assisted by UNESCO. Geoparks are about rocks, but also about people, society and culture. Geology, geoheritage, geotourism, economic development and public education are all vital elements for a Global Geopark. Geotourism, based on the observation and understanding of geology, is a growing part of the tourism market. While geo- tourism is not new, the development of the European Geoparks Network, Asian Geoparks Network and the parent Global Geoparks Network are providing models for engaging the public in the appreciation of geology that link sustainable economic development with the preservation and interpretation of geology.

This three day field trip will introduce Stonehammer Geopark and explore some of the localities that make it geologically and historically interesting. The trip will highlight features that made Stonehammer a successful geopark candidate, and examine the vital component of community engagement in developing Earth Science literacy.

Stonehammer encompasses 2500 square kilometres centered on historic Saint John, Canada's oldest incorportated city. Comprised of sixty geosites, the park stretches from Lepreau Falls Provincial Park in the west to the Fundy Trail Parkway near St. Martins in the east, and north to the villages of Norton and Hampstead. The geology of the park includes a billion years of stories. Rocks from eleven geologic time periods can be found within the park. In the more than 100 formations and igneous suites represented, there are numerous Group or Formation stratotypes and classic fossil localities. The region also has almost 200 years of geological exploration beginning with the geological surveys of Abraham Gesner.

This trip will visit the Precambrian and Cambrian terrane contact at the Reversing Rapids (Fig. 2), a site better known for high tides of the Bay of Fundy that push the river back-

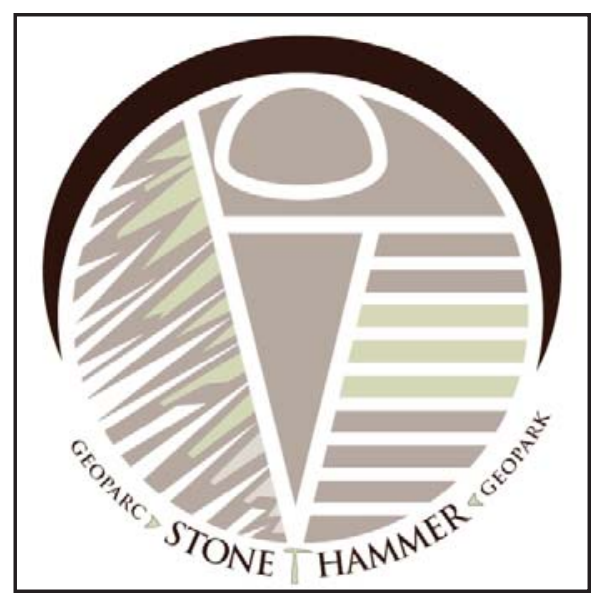

Figure 1. Stonehammer Geopark recognizes its history of geological and palaoentological exploration.

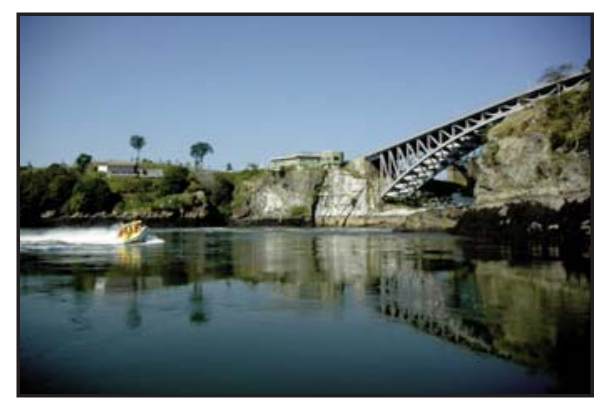

Figure 2. Terrane contact at the Reversing Rapids. Light grey marble of the Neoproterozoic Green Head Group (Brookville Terrane) below the bridge and dark grey shales of the Cambrian-Ordovician Saint John Group (Caledonia Terrane) downriver.

wards. The gorge at Reversing Rapids was visited by Charles Lyell in 1852 where he marvelled at the tidal phenomenon and visited the graphite mines that were then following seams in the Precambrian marble. Not far 


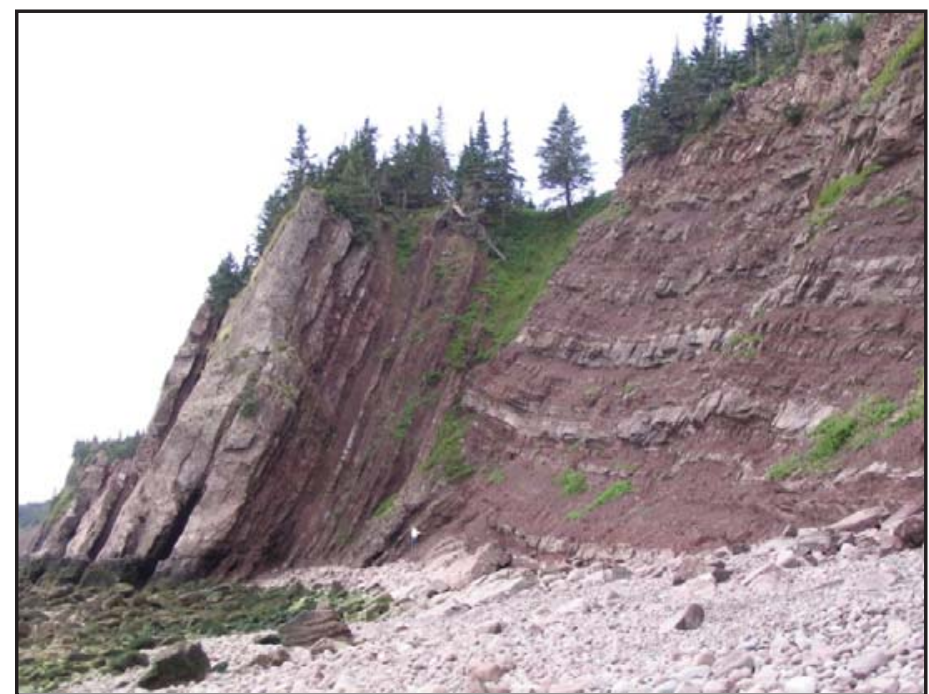

Figure 3. Megafan deposits of the Upper Carboniferous Tynemouth Creek Formation on the Bay of Fundy shoreline.

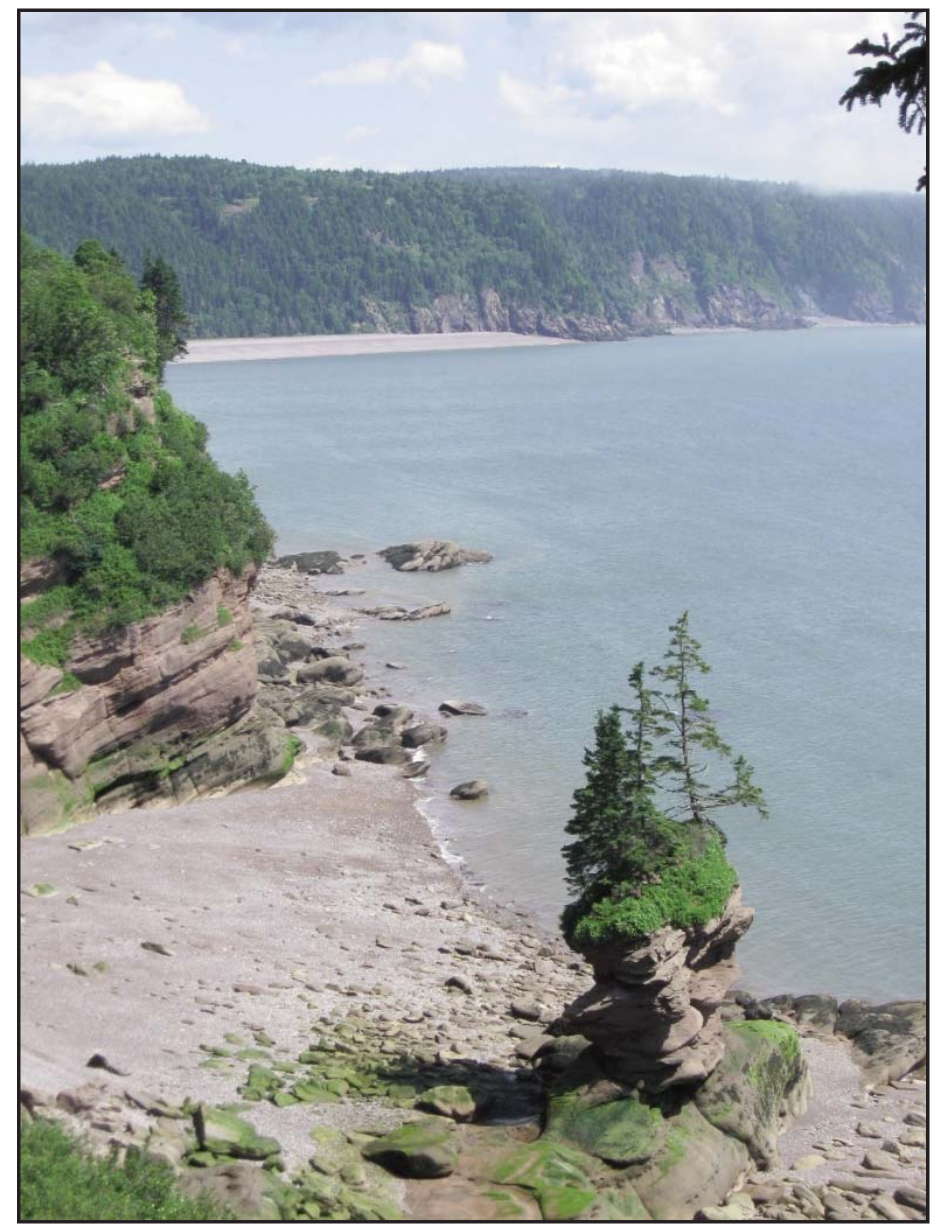

Figure 4. Triassic rocks of the Echo Cove Formation lie below the coastal trails of the Fundy Trail Parkway.

away the first Precambrian stromatolites described in a scientific paper can be reached by a short hike. CambrianOrdovician rocks of the Avalon Ter-

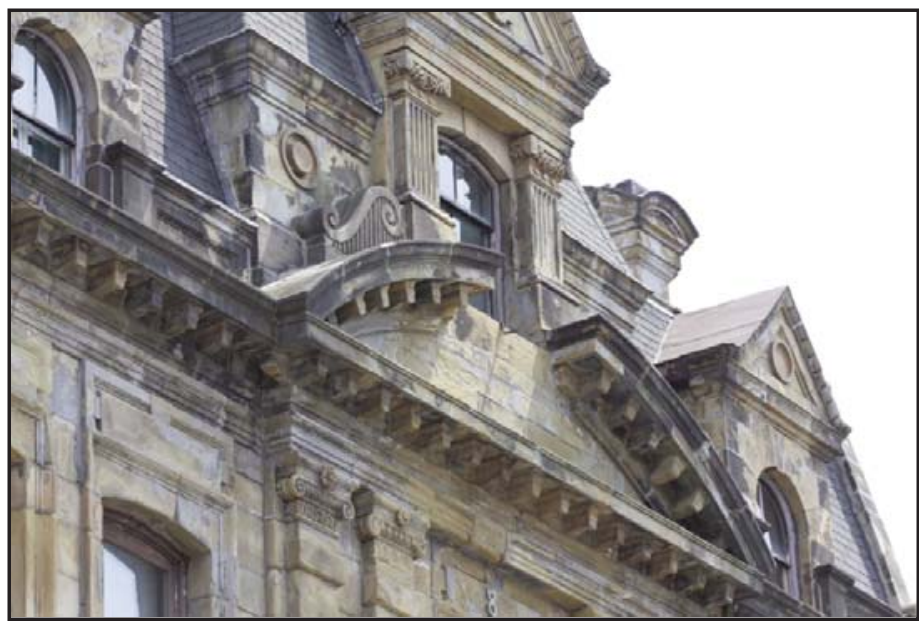

Figure 5. Building stones in Uptown Saint John connect the community to its history of a dimension stone industry.

rane that underlie the city centre were described in dozens of publications by Canada's Cambrian expert of the 19th century, George Frederic Matthew. He described a fauna of trilobites and small shelly fossils eliciting a visit by his American colleague Charles Doolittle Walcott. Matthew's young son William, later a world-renowned paleontologist at the American Museum of Natural History, found one of the world's largest trilobites in Cambrian rocks near the harbour. Carboniferous rocks outcrop along the Bay of Fundy. The trip will stop at the Upper Carboniferous 'Fern Ledges' where in 1914 British paleobotanist Marie Stopes, working on behalf of the Geological Survey of Canada, determined the age of shales made famous in 1868 by Charles Fred- eric Hartt and G.F. Matthew in William Dawson`s landmark publication Acadian Geology. Hartt, along with Samuel Scudder of Boston had described what were thought to be some of the world's oldest insects from this site in the 1860s. Further east can be seen the megafan deposits of the Tynemouth Creek Formation (Fig. 3) that have recently produced tetrapod footprints and trackways made by the giant 'millipede' Arthropleura.

The eastern border of Stonehammer is the Fundy Trail Parkway, a scenic hiking and driving route along the Triassic cliffs (Fig. 4) of the Bay of Fundy. Other places to see include the ice age deposits at the Irving Nature Park and building stones in historic Uptown Saint John (Fig. 5) rebuilt after the devastating Great Fire of 1877.

\section{ADDITIONAL INFORMATION}

The field trip will depart from Fredericton, about a 1.5 hour drive from Saint John. Two nights will be spent in Saint John where all sites in Stonehammer Geopark can be reached in less than an hour drive. Day 3 will be a half day visiting field sites before returning to Fredericton in the evening. Most sites are on roadsides, or are easy walking to light hikes on developed public trails. Some localities require short hikes of half an hour on undeveloped trails. Short boat tours or guided kayak excursions may be options. 